\title{
DETAILED GEOECOLOGICAL RESEARCH OF TERROIR WITH THE FOCUS ON GEORELIEF AND SOIL - A CASE STUDY OF KRÁTKE KESY VINEYARDS
}

\author{
VLADIMÍR FALŤAN ${ }^{1}$, LUCIA KRAJČÍROVIČOVÁ ${ }^{1}$, FRANTIŠEK PETROVIČ², MILOSLAV \\ $\mathrm{KHUN}^{3}$
}

${ }^{1}$ Department of Physical Geography and Geoecology, Faculty of Natural Sciences, Comenius University in Bratislava, Mlynská dolina, Ilkovičova 6, 84215 Bratislava 4, Slovak Republic; e-mail:vladimir.faltan@uniba.sk

${ }^{2}$ Department of Ecology and Environmental Sciences, Faculty of Natural Sciences, Constantine the Philosopher University in Nitra, Trieda A. Hlinku 1, 94974 Nitra, Slovak Republic; e-mail: fpetrovic@ukf.sk

${ }^{3}$ V. Clementisa 8, 90101 Malacky, Slovak Republic

\begin{abstract}
Faltan V., Krajčírovičová L., Petrovič F., Khun M.: Detailed geoecological research of terroir with the focus on georelief and soil - a case study of Krátke Kesy vineyards. Ekológia (Bratislava), Vol. 36, No. 3, p. 214-225, 2017.
\end{abstract}

\begin{abstract}
The aim of this research is to present the application of the detailed geoecological research for use by the identification of natural elements of terroir, based on the example of cadastral area Krátke Kesy. The characteristics of georelief (influencing the microclimate of vineyards) and soil characteristics (affecting the vineyard nutrition) are the most important elements of a terroir on a local scale. We present maps of 10 types of geoecological complexes in topic dimension, whose borders were allocated on the base of georelief as a leading factor of regionalization. Foot slopes, transport slopes and terraces prevail in the vineyard. Cultivated Haplic and Luvi-Haplic Chernozem of the Danube Lowland have excellent conditions for precision agriculture. The impact of soil factors on vineyards was evaluated with the use of accredited laboratory analysis. Using statistical methods, we confirmed the hypothesis that the relationship between observed relevant soil elements in the study area and sugar content of grape is direct, and between the soil elements and acids in must is indirect. The biggest dependence was seen for magnesium, zinc and copper. Research results were presented in the form of maps and tables that can find use in vineyard and landscape-ecological practice.
\end{abstract}

Key words: georelief, soil, vineyards, geoecological research, terroir, Marcelová, Slovakia.

\section{Introduction}

Nowadays, greater focus is put on the application of landscape ecological and geographical methodological procedures in practice. Detailed field geoecological research (Minár et al., 2001; Čech, Kunáková, 2012) could bring more information about the local conditions of agricultural areas including vineyards (Faltan et al., 2016). Bonfante et al. (2011) and Tomasi et al. (2013) also presented the relevance of natural elements of landscape for localization of vineyards and wine quality.

Vineyard landscape is a characteristic type of landscape cover of agricultural land because of warm climate areas in Slovakia. In recent years, the quality of Slovak wines is rising, which 
is confirmed by the numerous gold medals from many prestigious competitions and successful producers place more emphasis on origin appellation and terroir. On the other hand, the vineyard area is slowly decreasing (Lauko et al., 2013; Hanušin, Štefunková, 2015). Decreasing of vineyards is also a demonstration of the actual agricultural policy of EU (Lieskovský et al., 2013; Opršal et al., 2013; Tarasovičová et al., 2013; Havlíček et al., 2014; Lieskovský, Kenderessy, 2014; Bažík, Muchová, 2015). The exact measurement of vineyard areas and their changes is possible with geographical information systems (Matečný, 2014). In this context, a significant role is also played by the modeling of relief impact on microclimatic conditions (Matečný et al., 2010). Quantitative oriented vineyard production can be enriched by the results of landscape field research (Súlovský, Hriník, 2016; Gábor et al., 2016).

Many factors influence the quality of wine - from the natural elements of landscape as essential assumption for vineyard growing, through cultivation culture to technological procedures of winemakers. Terroir reflects the conviction that each wine reflects the environmental properties of the vineyard where the vine was grown (Unwin, 2012 in Dougherty et al., 2012).

Geoecological research brings valuable knowledge to winegrowers. In Slovakia, such connection is used only by a few companies. Exception includes, for example, Ravena Ltd established in Topolčianky. Local natural conditions of vineyards could be described in detail on topical scale. The complexes of topical dimension are described with different terms - geotope, ecotope, abiocomplex and so on. Geotope is the smallest, geographically undividable landscape spatial unit. The basic characteristic of topical dimension is that it is geographically quasi homogenous. Among the components and elements of topical dimension, complexes proceed their mutual vertical relations (Tremboš et al., 2009). Geotope components are the most important components of natural terroir vineyards: georelief, climate and soil with geological substrate.

Georelief plays a significant role by localization of vineyards. Its characteristics (altitude, orientation and inclination) significantly influence the microclimate and consequently also the success of vine growing in selected area (Bezák et al., 1999). Climatic conditions are an important limitation factor for vine growing in regional and choric dimension. On the level of geotope, the information about morphometric parameters of georelief could characterize the microclimate of vineyard and substitute the missing date from areas without meteorological bases.

The relationship between grape vine (Vitis vinifera), which due to the tough root system penetrates to the depth of several meters, and rock subsoil is well known. It is a geological structure that is the main factor of the soil formation that determines vine growing. Primarily, it is the soil that has an impact on the total quality of wine, that is, on its appearance, smell and taste (Kraus, Laštincová, 2011). Soil composition depends on the change of geological material due to the impact of physical, chemical and biological procedures. Quite barren and not very deep soil are suitable for grapevine growing (Dominé, 2005).

The article presents the application of procedures of geoecological research for the need of detailed knowledge of georelief and soil cover as a significant part of terroir. Field work and collection of soil samples were realized in the spring of 2017 in the vineyards of Ravena Ltd, located in the cadastral area of Krátke Kesy. We also verified the research hypothesis - if there is a direct statistical dependence between the occurrence of the element in the soil and the grape sugar content, between the same element and the acid content of the must will be indirect dependence. 


\section{Study area}

Study area is located in Marcelová village, concretely in the cadastral area of Krátke Kesy (Fig. 1). It belongs to the Nitra region and Komárno County. Marcelová village lies in an area of $35.75 \mathrm{~km}^{2}$, out of which Krátke Kesy occupies $17.7 \mathrm{~km}^{2}$. According to the viticulture division, the study area belongs to the South-Slovakian viticultural region. It is the hottest viticulture area in Slovakia and higher temperature contributes to a bigger sugar content. It also allows to grow varieties of later maturing vine varieties. According to the geomorphologic division of Slovakia (Mazúr, Lukniš, 1986), 2 geomorphological units are in the area that belongs to the Podunajská lowland pass - Podunajská plane and Podunajská upland. Vineyards planted on the loess upland and plane, with clay - loamy sandy to loamy soils, have good water holding. It provides enough moisture to vineyards even in the hottest and the driest months. The vineyard is grown on planes, except for the vineyards grown on south, southeast and southwest slopes (MP SR, 2014). Average altitude of the cadastral area is $140 \mathrm{~m}$ above sea level. Closely studied vineyard is located on plane to mild slope with an average altitude of $129 \mathrm{~m}$ and area of $0.47 \mathrm{~km}^{2}$.

According to the Geological map of Slovakia (ŠGÚDŠ, 2013), the south part of the area on Podunajská plane is formed by fluvial sediments. With the direction to Podunajská upland, the fluvial sediments change with fluvial and eolian sediments. North part of the area, which is also the highest part of the area is created by sands, gravels, clays and coal clays from

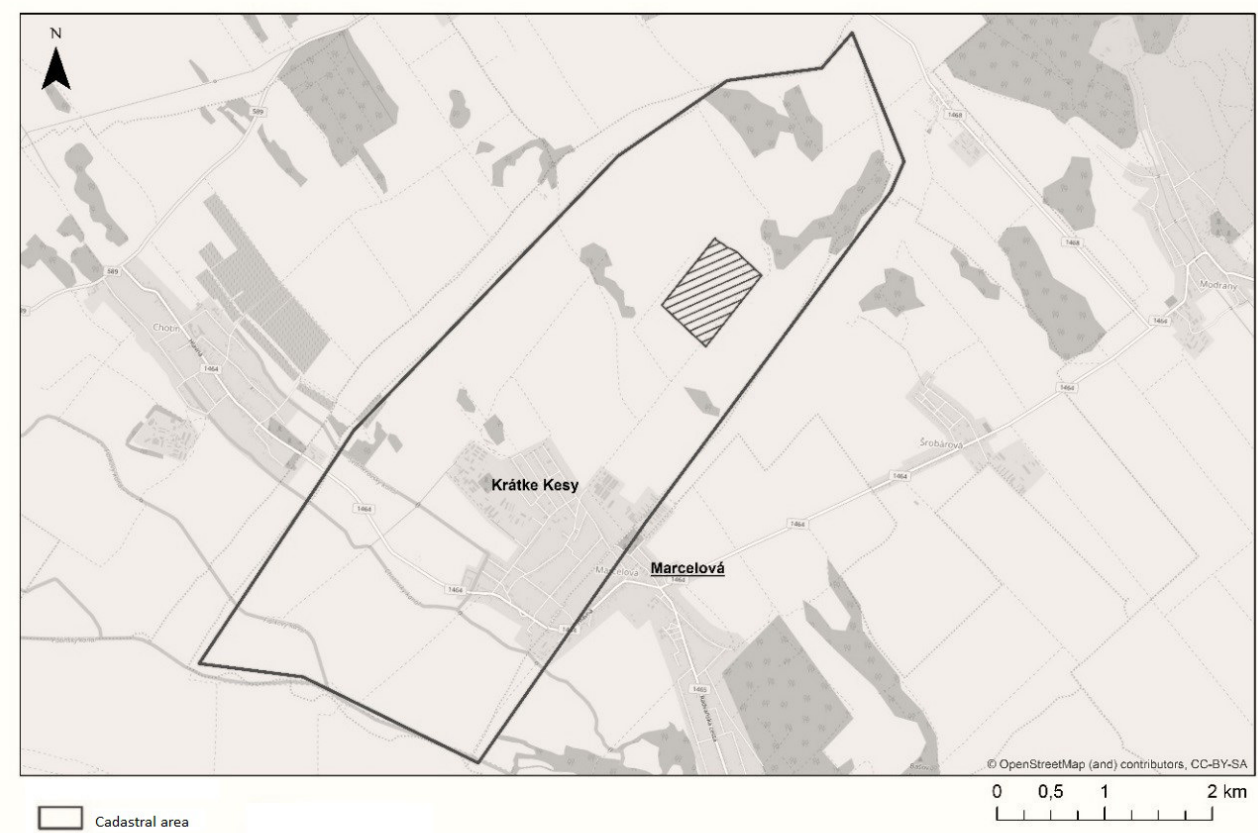

Fig. 1. Localization of studied area in cadastral area of Krátke Kesy. 
the era of Neogene. The studied area is located in a warm climate area, which is a warm very dry region with mild winters. Here, the number of summer days is above 50 (Lapin et al., 2002). The average annual temperature in the area has risen by $1{ }^{\circ} \mathrm{C}$ in 2016 as compared to the average of years 1951-2010, which may also affect the phenological phase of the grape vine. The average air temperature for 2016 was $11.3^{\circ} \mathrm{C}$ and in the vegetation period in 2016 , it was $17^{\circ} \mathrm{C}$. The biggest stream of Patinský kanál flows through the studied area; there is no stream that flows directly through the vineyard. The database of bonitated soil - ecological units for the area states the occurrence of Haplic Chernozems, locally Stagni-Haplic Chernozems and Calcaric Arenosols. Potential natural vegetation is created by oak forests, in higher altitude by oak-hornbeam forests (Maglocký, 2002).

\section{Material and methods}

Detailed relief and soil type research was part of the geoecological research that was implemented in topical dimension. We proceeded according to the work of Minár et al. (2001), Faltan et al. (2016). Preparation phase included the analysis of text, map and database materials.

Basic material about the geological structure of the selected area was the Geological map of SR 1:50 000, which is freely accessible on the website of State Geological Institute of Dionýz Štúr. Map legend was united on the basis of occurring litotype. Georelief characteristic of the studied area was conducted based on the Basic map of SR 1:10 000. Contour lines were digitalized by ArcGIS and based on this, the digital model of relief with the help of Topo to raster with cell of size 20 was created. Out of this, an insolation raster was created with the help of Area Solar Radiation, where default settings were retained. It was created for each half an hour of every $7^{\text {th }}$ day in year. For the selected vineyard, the rasters of slope inclinations were derived with the help of Slope, orientation with Aspect.

Provisional pedogeographical characteristic was developed on the basis of bonitated soil - ecological units' map in the scale of 1:5 000 (BPEJ; Linkeš et al., 1996). Climate characteristic was conducted on the basis of data provided by SHMÚ. For the complete cadastral area, the characteristic of landscape cover was conducted. Identification of individual classes was based on the methodology CORINE Land Cover in scale 1:50 000 (Feranec, Otahel, 1999). All the classes were mapped on the $4^{\text {th }}$ hierarchical level, where the minimal mapped area measured 4 ha. However, because of the viticulture topic, the areas of vineyards were disaggregated on the $5^{\text {th }}$ hierarchical level with minimum of mapped area of 0.1 ha on the basis of extended methodology in the scale of 1: 10000 (Druga et al., 2015). Classes 1.2.1.2 Special facilities areas and 5.1.1.2 Canal were also taken from this methodology. The characteristic of landscape cover and georelief worked as a base for the definition of basic areas of geoecological research and localization of research points (tesserae).

Location 9 of tesserae was localized by GPS. The basic areas of research and location of research points were determined evenly on the base of relief as a leading factor; however, they were also adjusted to soil types and subtypes stated in the map BPEJ. Their number was adjusted to practical options and to Notice 338/2005; probe digging was executed by excavator.

Soil type and subtype was determined on the research point and for each soil horizon, its thickness, granularity and shell content was marked; subsequently, the soil formation substrates were also described. The classification of soil types and subtypes was conducted according to the Morphogenetic classification systems of soils of Slovakia (VÚPOP, 2013), which allows, by cultivated subtypes, the subtype units' combination (for example: Luvi-Haplic Cultisol). For each soil probe sample, minimum of $1 \mathrm{~kg}$ was removed from a depth of $20-40 \mathrm{~cm}$ and $50-70 \mathrm{~cm}$. Samples were sent for laboratory analysis to the accredited laboratory - the Debrecen Soil Laboratory.

Subsequently, map and database of geo ecological complexes was created with the work procedure of Faltan et al. (2016). Georelief was used as a leading factor; on the basis of georelief, a mapping of morphological spatial types of elementary forms of relief was conducted (adjusted by Tremboš in Minár et al., 2001). The only exception by border determination was the division of elementary form determined as terrace, on the basis of basic soil type and subtype as per BPEJ. For geo ecological complexes were completed attributes about geological substrate, soil types and subtypes, potential natural vegetation, insolation, orientation and average incline. Insolation classification was calculated from the relief insolation map using the Zonal Statistics Tool as a Table, with average value for each geocomplex. We created 3 categories of insolation on the area of the selected vineyard. We used the same procedure by calculating the average incline for each geocomplex. 
On the base of our field research, we updated the soil types and subtypes in the area of selected vineyards and created a map of real soil units. The mapping of original soil units was conducted on the basis of geo ecological research after isolation of information about the impact of agricultural production on the character of soil land cover. Results of laboratory soil analysis was conducted in the accredited Debrecen Soil Laboratory (Hungary) and sugar content data and content of acids in must were provided by the winemakers; the data was processed using regression analysis in MS Excel.

\section{Results and discussion}

Characteristics of geotopes contains, except for geological substrate data, soil data, georelief data, vegetation data also hydrological and climate data. In this case, for a more detailed description of the microclimatic conditions, it would be necessary to install a meteorological station in the vineyard. In further text, we have stated the characteristics of pedological substrate, soils, georelief, insolation and potential natural vegetation of the types of geoecological complexes on topical level (Table 1).

T a b l e 1. Types of geoecological complexes on selected vineyards in Krátke Kesy.

\begin{tabular}{|c|c|c|c|c|c|c|c|c|}
\hline TGK & Landform & Substrate & BPEJ & Soil type & $\begin{array}{c}\text { Insolation } \\
\text { category }\end{array}$ & $\begin{array}{c}\text { Average } \\
\text { slope angle } \\
{\left[{ }^{\circ}\right]}\end{array}$ & Exposition & $\begin{array}{c}\text { Area } \\
{[\%]}\end{array}$ \\
\hline 1 & $\begin{array}{l}\text { Transport } \\
\text { slope } \\
\text { (convex) }\end{array}$ & $\begin{array}{l}\text { Eolic-deluvial } \\
\text { sediments }\end{array}$ & $\begin{array}{l}\text { Haplic } \\
\text { Chernozems }\end{array}$ & $\begin{array}{l}\text { Luvi-Haplic } \\
\text { Chernozems } \\
\text { (cultivated) }\end{array}$ & 2 & 2.47 & W & 3.60 \\
\hline 2 & Terrace & $\begin{array}{l}\text { Fluvial-eolic } \\
\text { sediments } \\
\end{array}$ & \begin{tabular}{|l|} 
Haplic \\
Chernozems \\
\end{tabular} & \begin{tabular}{|l|} 
Haplic \\
Chernozems \\
\end{tabular} & 1 & 0.36 & SW & 18.22 \\
\hline 3 & Foot slope & $\begin{array}{l}\text { Fluvial-eolic } \\
\text { sediments }\end{array}$ & $\begin{array}{l}\text { Haplic } \\
\text { Chernozems }\end{array}$ & $\begin{array}{l}\text { Haplic } \\
\text { Chernozems } \\
\text { (cultivated) }\end{array}$ & 1 & 0.44 & SW & 33.38 \\
\hline 4 & Foot slope & $\begin{array}{l}\text { Eolic-deluvial } \\
\text { sediments }\end{array}$ & $\begin{array}{l}\text { Haplic } \\
\text { Chernozems }\end{array}$ & $\begin{array}{l}\text { Haplic } \\
\text { Chernozems } \\
\text { (cultivated) }\end{array}$ & 1 & 0.76 & $S$ & 18.88 \\
\hline 5 & $\begin{array}{l}\text { Transport } \\
\text { slope } \\
\text { (convex) } \\
\end{array}$ & $\begin{array}{l}\text { Eolic-deluvial } \\
\text { sediments }\end{array}$ & $\begin{array}{l}\text { Haplic } \\
\text { Chernozems }\end{array}$ & $\begin{array}{l}\text { Haplic } \\
\text { Chernozems } \\
\text { (cultivated) }\end{array}$ & 2 & 2.07 & S & 5.41 \\
\hline 6 & $\begin{array}{l}\text { Transport } \\
\text { slope (con- } \\
\text { cave) }\end{array}$ & $\begin{array}{l}\text { Eolic-deluvial } \\
\text { sediments }\end{array}$ & $\begin{array}{l}\text { Haplic } \\
\text { Chernozems }\end{array}$ & $\begin{array}{l}\text { Haplic } \\
\text { Chernozems } \\
\text { (cultivated) }\end{array}$ & 3 & 3.58 & SW & 5.13 \\
\hline 7 & $\begin{array}{l}\text { Transport } \\
\text { slope } \\
\text { (concave) } \\
\end{array}$ & $\begin{array}{l}\text { Eolic-deluvial } \\
\text { sediments }\end{array}$ & $\begin{array}{l}\text { Haplic } \\
\text { Chernozems }\end{array}$ & $\begin{array}{l}\text { Luvi-Haplic } \\
\text { Chernozems } \\
\text { (cultivated) }\end{array}$ & 3 & 2.99 & SW & 6.85 \\
\hline 8 & $\begin{array}{l}\text { Transport } \\
\text { slope } \\
\text { (convex) }\end{array}$ & $\begin{array}{l}\text { Eolic-deluvial } \\
\text { sediments }\end{array}$ & $\begin{array}{l}\text { Haplic } \\
\text { Chernozems }\end{array}$ & $\begin{array}{l}\text { Haplic } \\
\text { Chernozems } \\
\text { (cultivated) }\end{array}$ & 2 & 2.74 & SW & 3.15 \\
\hline 9 & Terrace & $\begin{array}{l}\text { Fluvial-eolic } \\
\text { sediments }\end{array}$ & $\begin{array}{l}\text { Calcaric } \\
\text { Arenosols }\end{array}$ & \begin{tabular}{|l} 
Haplic \\
Chernozems \\
(cultivated)
\end{tabular} & 1 & 0.28 & SW & 1.06 \\
\hline 10 & Terrace & $\begin{array}{l}\text { Fluvial-eolic } \\
\text { sediments }\end{array}$ & $\begin{array}{l}\text { Stagni-Haplic } \\
\text { Chernozems }\end{array}$ & $\begin{array}{l}\text { Haplic } \\
\text { Chernozems } \\
\text { (cultivated) }\end{array}$ & 1 & 0.28 & SW & 4.32 \\
\hline
\end{tabular}


In the studied vineyard, we set boundaries of each type of geoecological complexes (TGK) on the basis of georelief. The newly created areas were assigned date regarding the litotype, soil types and subtypes - according to the registry of bonitated soil - ecological units (BPEJ) (VÚPOP, 2013) and according to the realistic findings of our research and insolation classification as well. Average incline and orientation of georelief were also added. This way, we classified 10 geoecological complexes (Fig. 2), which are characterized in Table 2.

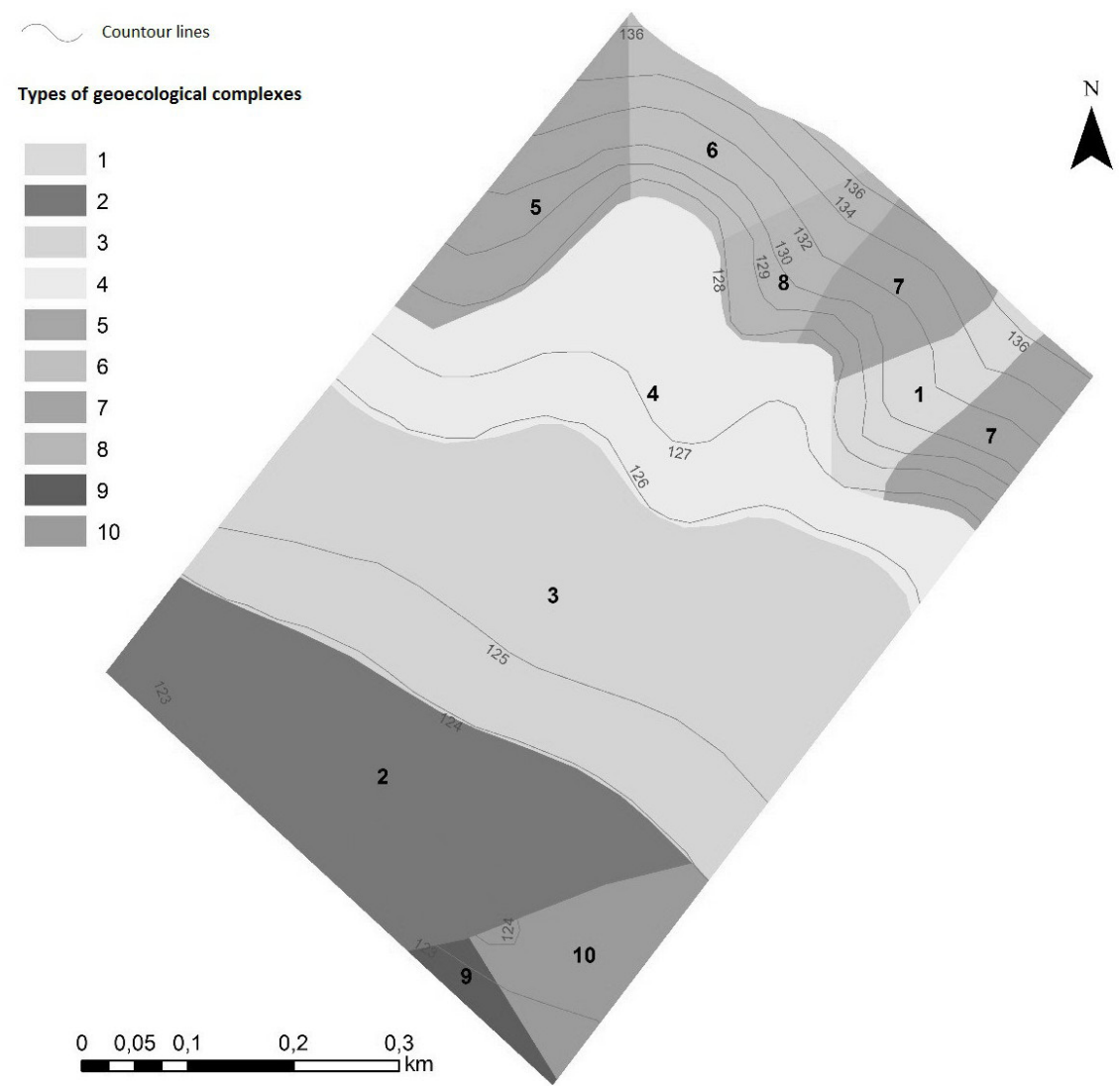

Fig. 2. Types of geoecological complexes in the selected area in Krátke Kesy.

Out of the morphological-positional types of elementary forms of georelief, the foot slopes prevail, which represent $52.26 \%$ of the selected vineyards. The morphological complexes of transport slopes represent $24.14 \%$ and terrace complexes $23.6 \%$. In the studied area, two types of litotype occur. One that prevails are the eolic-deluvial sediments $(43.02 \%$ of vineyard area); they are located on transport and foot slopes. The other litotype is represented by the fluvial-eolic sediments that are located mainly on terraces. 
T a b l e 2. Results of soil laboratory analysis.

\begin{tabular}{|c|c|c|c|c|c|c|c|c|c|c|c|}
\hline \multirow{3}{*}{ Variety } & \multirow{3}{*}{$\begin{array}{l}\text { Number } \\
\text { of probe }\end{array}$} & \multicolumn{10}{|c|}{ Contents of accessible nutrients extract in Mehlich III. (mg.kg $\left.{ }^{-1}\right)$} \\
\hline & & \multicolumn{6}{|c|}{ Macro elements - macro nutrients } & \multicolumn{4}{|c|}{ Micro elements } \\
\hline & & $\mathbf{N}$ & Ca & $\mathrm{Mg}$ & $\mathbf{K}$ & $\mathrm{S}$ & $\mathbf{P}$ & $\mathrm{Na}$ & $\mathbf{C u}$ & Mn & Zn \\
\hline Alibernet & 4 & 1.5 & 9.6 & 140.5 & 86.5 & 3.7 & 14.5 & 5.1 & 1.6 & 116.5 & 0.4 \\
\hline Cabernet Sauvignon & 1.2 .3 & 1 & 7.23 & 75.3 & 91.16 & 1.26 & 26.33 & 1.16 & 1.15 & 50.16 & 0.216 \\
\hline Blaufränkisch & 6 & 1 & 0.1 & 183.5 & 85.5 & 14.45 & 23.5 & 0.2 & 2.55 & 207 & 0.5 \\
\hline Palava & 9 & 1 & 0.1 & 133 & 104 & 2.95 & 24 & 0.2 & 3.45 & 168 & 0.7 \\
\hline Riesling & 8 & 1 & 8 & 56 & 53.5 & 1.65 & 23.5 & 1.1 & 0.85 & 35 & 0.2 \\
\hline Pinot gris & 5 & 25.5 & 12 & 124 & 106 & 16.3 & 37 & 3.1 & 1.2 & 55.5 & 0.45 \\
\hline Sauvignon & 7 & 1 & 0.1 & 88.5 & 102.5 & 3.65 & 11 & 0.2 & 2.8 & 203.5 & 0.25 \\
\hline
\end{tabular}

Geological complexes with highest solar power ( $3^{\text {rd }}$ insolation category) are logically on concave transport slopes, where the insolation values reach up to $880.1-885 \mathrm{kWh} / \mathrm{m}^{2}$ per year. Flare category number $2\left(875.1-880 \mathrm{kWh} / \mathrm{m}^{2}\right.$ per year) are located on terraces and foot slopes, which represent $75.69 \%$ of the area. Vineyard orientation is south to west; average incline of the area is $1.04{ }^{\circ} \mathrm{C}$.

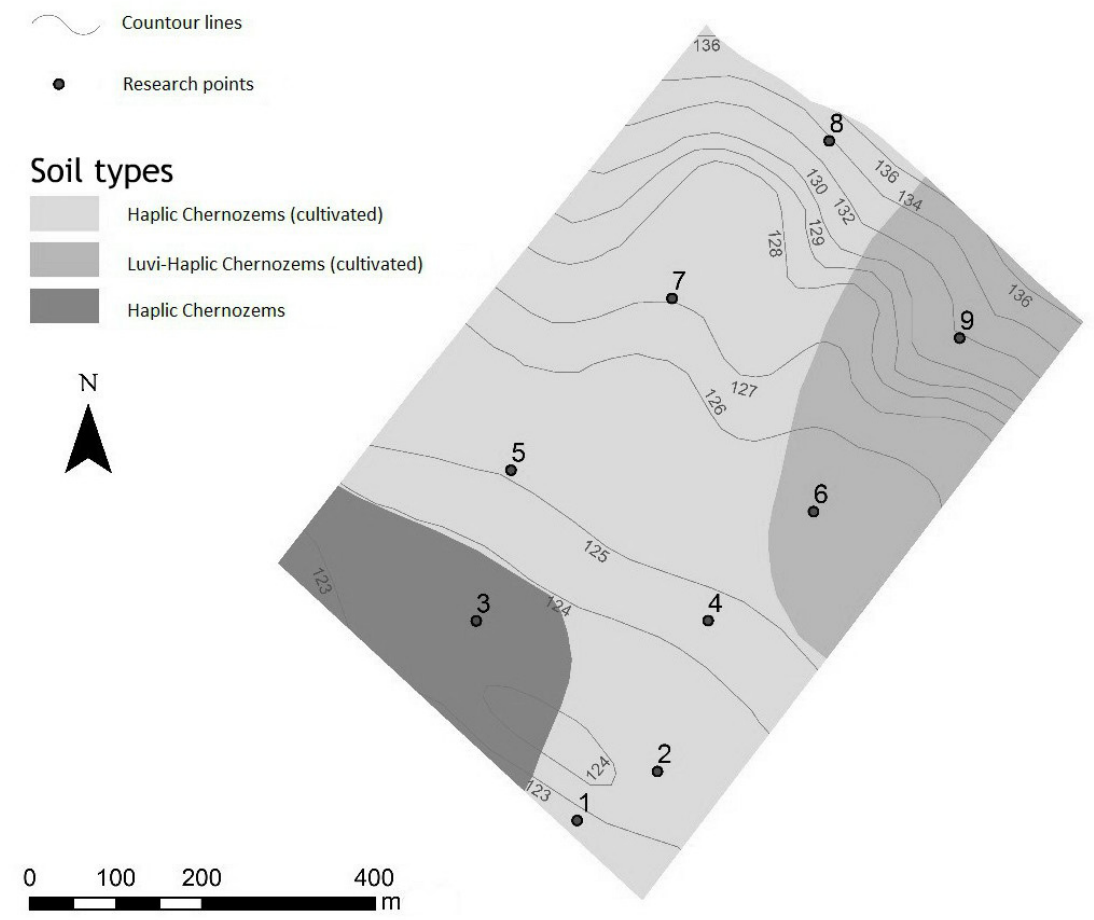

Fig. 3. Real soil types and subtypes in selected area. 
Prevailing soil type in the studied area was Haplic Chernozems; in higher altitudes, it was alternating with Luvi-Haplic Chernozems. Chernozems are located on loess, loess clay and on older alluvial sediments, where there has not been any flooding for a long time. Nowadays, in the area of vineyard, the cultivated Haplic Chernozems prevails (Fig. 3). The peculiarity of vineyard soils is their cultivation by establishing a vineyard, called as rigolation. By rigolation, the rollover and shuffle of the top humus horizon with the lower layers occurs. Soil is aerated and humus substances penetrate lower into its profile. At the same time, the impact of parental rock on vineyard increases. Soil is characterized by deep humus horizon (50-101 $\mathrm{cm}$ ) and quality structure. The occurrence in BPEJ stated Stagni-Haplic Chernozems and Calcaric Arenosols was not confirmed in the studied area.

Nourishment and manuring of soil ensure the equilibrium of growth of the vine as well as its fruitfulness and good quality of grapes. There are many problems concerning the growing of vine. The main reason resides in improper nourishment. In order to be able to propose optimal and adequate manuring and processing of soil, it is necessary and important for wine growers to get a laboratory soil analysis. The results of these laboratory soil analysis are stated in the Table 2. Extractive solution called Mehlich III facilitate better accessibility of nutrients for plants in the soil. The extract contains phosphorus, potassium, calcium, magnesium as well as sodium, copper, manganese, zinc and other chemical elements. By using the method of Kjelhdal, it is possible to determine the amount of overall nitrogen, while the important chemical element is organic nitrogen, which can be found in the soil predominantly in this form (98-99\%). The organic nitrogen is a supply form that can be used by vine until its mineralization. The advantage is the better ability of reagent Mehlich III buffering $\mathrm{pH}$ by extraction, so there is no increase above 2.9. Disadvantage of this method is that it is not able to differentiate the nutrients that are in the soil solution from the nutrients that are in soil bound by different strength (Vanek et al., 1996). It is necessary to state that the ratio of accessible nutrients creates only a small share of its total content in soil (approx. to 1\%) and it represents mostly those nutrients that are soluble in the soil solution, bound in desorption soil complex, as with the nutrients bound in soil in compounds are soluble in weak acids or alkalis.

Data concerning the sugar content and the content of acids in the must are stated in Table 3. The sugar content of a grape is expressed in the scale of normalized must measure; it shows the amount of sugar in the must and so the potential content of alcohol in a wine. By evaluating the parameters of ripeness, it is necessary to take into account the content of typical acids having the same sort in the must. The aim is to get an acid ratio which would correspond to a given variety and to avoid low or high values. The content of acids in the must is expressed in gram per liter (Pavloušek, 2011).

T a b l e 3. Sugar content of grape, acid content in must and $\mathrm{pH}$ of must in observed varieties.

\begin{tabular}{|l|c|c|c|}
\hline Variety & $\begin{array}{c}\text { Sugar } \\
\text { content } \\
\left({ }^{\circ} \mathbf{N M}\right)\end{array}$ & $\begin{array}{c}\text { Acid } \\
\text { content in } \\
\text { must (g/l) }\end{array}$ & $\begin{array}{c}\text { pH of } \\
\text { must }\end{array}$ \\
\hline Alibernet & 19.6 & 7.5 & 3.29 \\
\hline Cabernet Sauvignon & 17.8 & 12.3 & 3.04 \\
\hline Blaufränkisch & 21 & 8.6 & 3.16 \\
\hline Palava & 24.2 & 7.75 & 3.22 \\
\hline Riesling & 19.1 & 10.9 & 2.99 \\
\hline Pinot gris & 20.65 & 9.64 & 3.07 \\
\hline Sauvignon & 19.6 & 12.55 & 3.02 \\
\hline
\end{tabular}


In Table 4, the basic statistical characteristics of the most significant determined reliance have been stated. The power of dependence between the two variables expresses the coefficient of correlation of Pearson $-r$, which acquire the values $<-1 ; 1>$. In majority of relations, there were low values of dependence, mostly weak linear or weak indirect linear dependencies that are in the interval $<-0.5 ; 0.5>$ (if the values are close to 0 , in that case, the elements are independent). The characteristic of selected and the most important macro- and micro-elements were adapted according to the work of Pavloušek (2011). The magnesium influences the photosynthesis, participates in the making of amino acids and improves the health of the grape. Dependence of the content of acids in the must against the content of magnesium in the soil have the value -0.76. It results in high indirect linear dependence. Zinc is important for quality pollination and fertilization of compound flower and at the same time, it participates in the synthesis of proteins and vegetable hormones. Copper influences the biochemical reactions in the vine and participates in the making of chlorophyll. Copper has a significant importance by making of saccharides. Manganese is important during the photosynthesis and influences the activity of an enzymatic activity in vine and participates in the regulation of farming of a plant with water.

$\mathrm{T}$ a b l e 4. Basic characteristics of observed dependences between the contents of selected elements, sugar content and acid content in must.

\begin{tabular}{|l|l|c|c|c|}
\hline \multirow{2}{*}{ Element content $\mathbf{( x )}$} & $\begin{array}{l}\text { Dependent variable } \\
\mathbf{( y )}\end{array}$ & formula & $\mathbf{R}^{\mathbf{2}} \mathbf{( \% )}$ & $\mathbf{r}$ \\
\hline \multirow{3}{*}{$\mathrm{Mg}$} & Sugar content & $\mathrm{y}=0.0254 \mathrm{x}+17.375$ & 30.26 & 0.55 \\
\hline \multirow{3}{*}{$\mathrm{Zn}$} & Acid content & $\mathrm{y}=-0.0361 \mathrm{x}+14.026$ & 57.98 & -0.76 \\
\hline \multirow{3}{*}{$\mathrm{Cu}$} & Sugar content & $\mathrm{y}=10.416 \mathrm{x}+16.237$ & 87.64 & 0.93 \\
\cline { 2 - 6 } & Acid content & $\mathrm{y}=-9.2385 \mathrm{x}+13.476$ & 65.14 & -0.81 \\
\hline \multirow{3}{*}{$\mathrm{Mn}$} & Sugar content & $\mathrm{y}=1.5299 \mathrm{x}+17.305$ & 56.08 & 0.74 \\
\cline { 2 - 6 } & Acid content & $\mathrm{y}=-0.6371 \mathrm{x}+11.129$ & 9.19 & -0.30 \\
\hline
\end{tabular}

If we compare the results of analysis with some criteria of evaluation of results of soils infusion by using the method Mehlich III, according to the regulation 151/2016 (regulation states in section 4 only the soil reaction and criteria for P, K and Mg). In the work of Pavloušek (2011), it is also possible to find criteria for Ca and many micro elements. We can state that according to the criteria of the content of particular nutrients, it is only magnesium which is the closest.

The soil reaction is, as per the stated regulation, neutral up to alkaline ( $\mathrm{pH} 6.73-7.59)$. In Table 4, we can see the obvious high positive correlation of sugar content with the content of zinc. This dependence is difficult to explain correctly. Zinc is present on sugar phosphorylation, however, correlation with phosphor shows almost no positive correlation (correlation coefficient 0.23 ). It is possible that the usage of sulphur form of potassium fertilizers in vineyards have as a result higher content of sugar in grapes (Torma, 1999). This is also not the explanation of correlation coefficient between sugar content and content of $\mathrm{K}$ in the extract is quite low 
(0.42).

Pavloušek (2011) states that some macroelements caused lower accessibility of other elements. For example, nitrogen lowers the accessibility of $\mathrm{Cu}$ for vineyard, phosphor lowers the accessibility of $\mathrm{Zn}$ and potassium lowers the accessibility of $\mathrm{Mg}$. Very significant is the antagonism of potassium and magnesium. The ratio between $\mathrm{K}$ and $\mathrm{Mg}$ should be between $1.7: 1$ to $5: 1$; optimum is $2: 1$. In each investigated variety, this ratio is variable and it is getting to the optimum on different levels, suitable for Blaufränkisch. It is interesting for white must variety Sauvignon and blue must variety Cabernet Sauvignon. The basic and irreplaceable nutrient for vineyard is nitrogen, plant receives it in the form of $\mathrm{NO}_{3}$ and $\mathrm{NH}_{4}+$. The key macro nutrient is also potassium; vineyard is very sensitive to its shortage.

By the analysis of this type, it is necessary to take into account the impact of rainfall on nutrients intake. For example, when there is a heavy rainfall, the vineyard at first receives nitrogen and then potassium. The intake of $\mathrm{Ca}+\mathrm{Mg}$ positively correlates with the amount of rainfall; negative correlation shows intake of $\mathrm{K}: \mathrm{Mg}$ with rainfall amount. Part of the contribution about the analysis of nutrients' intake of vine represents the first approach to the topic. For further research, it would be necessary to implement the sampling in bigger area and add information from Geochemical atlas of SR, soil part (Čurlík, Šefčík, 1999). Similarly, the analysis of observed elements in must for each variety would be essential. Then, the transfer coefficient - relations of elements' concentration in plants and their significant products to their total concentration in soil, could also be used. It would surely be interesting to observe the contents of some micro elements in the final product - in wine (Galani-Nikolakaki, Kallithrakas-Kontos, 2007).

By comparing the values of sugar content and the content of acids in each variety in the selected area with average values according to the publication of Ampelografia ČSSR (Pospíšilová, 1981), we found out that the sugar content in grapes is higher in almost all of the growing sorts and acid content is average or lower. Specific conditions of the observed terroir are beneficial for growing vines with higher sugar content and high content of alcohol. By the impact of climatic changes and trends of air warming, we suppose an increase in the sugar content of must.

\section{Conclusion}

Our work was aimed to present the application of detailed geoecological research methods for use by identification of natural elements of terroir on the example of cadastral area Krátke Kesy. The characteristics of georelief belong to the most important procedures on a local scale that affect the microclimate of vineyards and soil properties influencing the vineyard nutrition.

In a topic dimension, types of geocomplexes were created, where mainly georelief determined their borders. In their description, information about their litotype, soil types, subtypes, potential natural vegetation and insolation category was also stated. In this way, 10 types of geoecological types were created. Out of the morphologic-positional types of elementary forms of georelief, feet (colluvial) slopes prevail. They represent $52.26 \%$ of the chosen vineyards. Morfocomplexes of transport slopes occupy $24.14 \%$ and morfocomplexes of terraces $23.26 \%$. We can state the manifestation of foothill zonality in the area (occurrence of Haplic Chernozems and Luvi-Haplic Chernozems). 
On research points, we characterized the real occurrence of soil types and subtypes within field research. Soil map was consequently created. Out of individual tesserae, samples were withdrawn and sent for a soil analysis. The number of research points was limited by accessibility of vineyard, agricultural legislation and financial possibilities of research.

Results of laboratory analysis, together with data of sugar content and content of acids in must, were used for the evaluation of soil factors' impacts on growing of the vine. Through regression analysis, we can state that the observed soil elements have mainly a direct linear impact on sugar content of grape and indirect impact on the content of acids in must. The biggest dependence was seen for magnesium, zinc and copper.

Findings of this work are essential mainly for vine growers. Before their application, we recommend a detailed consultation with several experts, mainly winemakers and enologists. The results can also be used for landscape ecological praxis and other scientific disciplines.

\section{Acknowledgements}

Publication was created within solving of projects supported by grants of Slovak Research and the Development Agency No. APVV-15-059; and Grant Agency of the Ministry of Education of Slovak Republic and Slovak Academy of Science No. VEGA 1/0421/16. Field work was realized through the cooperation with the viticultural company Ravena Ltd.

\section{References}

Bažik, J. \& Muchová Z. (2015). Land consolidation in Slovakia, where it hangs? Research for Rural Development, 1, 201-217. Bezák, V., Suk, M. \& Vanek L. (1999). Kameň a víno. Bratislava: Vydavatelstvo Dionýza Štúra.

Bonfante, A., Basile, A., Langella, G., Manna, P. \& Terribile F. (2011). A physically oriented approach to analysis and mapping of terroirs. Geoderma, 167-168, 103-117. DOI: 10.1016/j.geoderma.2011.08.004.

Čech, V. \& Kunáková L. (2012). Geoekologický výskum a geoekologická databáza (na príklade katastrálneho územia obce Kolinovce) Geografický Časopis, 64(1), 29-46.

Čurlík, J. \& Šefćík P. (1999). Geochemický atlas SR. Čast V. - Pôdy. Bratislava:VÚPOP.

Dominé, A. (2005). Víno. Bratislava: Vydavatel'stvo SLOVART.

Dougherty, P. H. (Ed.) (2012). The geography of wine. Regions, terroir and techniques. New York: Springer.

Druga, M., Faltan, V. \& Herichová M. (2015). Návrh modifikácie metodiky CORINE LandCover pre účely mapovania historických zmien krajinnej pokrývky na území Slovenska v mierke 1: 10000 - príkladová štúdia historického k. ú. Batizovce. Geographia Cassoviensis, 9(1), 17-34.

Faltan, V., Pírová, L. \& Petrovič F. (2016). Detailed mapping of geocomplexes in the vineyard landscape. Folia Oecologia, 43(2), 138-146.

Feranec, J. \& Otahel' J. (1999). Mapovanie krajinnej pokrývky metódou CORINE v mierke 1 : 50 000: návrh legendy pre krajiny programu Phare. Geografický Časopis, 51(1), 19-44.

Gábor, M., Faltan, V. \& Petrovič F. (2016). Quantitative and qualitative approaches of delineation in detailed mapping of vineyard landscape. Case study: vicinity of Pezinok (Slovakia). Ekológia (Bratislava), 35(3), 240-252. DOI: 10.1515/ eko-2016-0019.

Galani-Nikolakaki, S.M. \& Kallithrakas-Kontos N.G. (2007). Elemental content of wines. In P. Szefer \& J.O. Nriagu (Eds.), Mineral components in foods. Boca Raton:Taylor and Francis.

Hanušin, J. \& Štefunková D. (2015). Changes in vine-growing landscape diversity in the hinterland of Svätý Jur town in 1896-2011 (in Slovak). Geografický Časopis, 67(3), 243-259.

Havlíček, M., Pavelková, R., Frajer, J. \& Skokanová H. (2014). The long-term development of water bodies in the context of land use: The case of the Kyjovka and Trkmanka river basins (Czech Republic). Moravian Geographical Reports, 22(4), 39-50. DOI: 10.1515/mgr-2014-0022.

Kraus, I. \& Laštincová J. (2011). Slovenské vinohradníctvo a jeho terroir očami geológa [online].Vinič a víno, 2, 43-45. Dostupné na internete: http://www.vinicavino.sk/wp-content/uploads/2011/06/VINICaVINO_02_2011_vnutro. pdf[cit. 4.1.2017] 
Lapin, M., Faško, P., Melo, M., Štastný, P. \& Tomlain J. (2002). Klimatické oblasti $1: 1000$ 000. In Atlas krajiny SR (p. 95). Bratislava: MŽP SR, Banská Bystrica: SAŽP.

Lauko, V., Tolmáči, L., Križan, F., Gurňák, D. \& Cákoci R. (2013). Geografia Slovenskej republiky. Humánna geografia. Bratislava: Geografika.

Lieskovský, J., Kanka, R., Bezák, P., Štefunková, D., Petrovič, F. \& Dobrovodská M. (2013). Driving forces behind vineyard abandonment in Slovakia following the move to a market-oriented economy. Land Use Policy, 32, 356-365. DOI: 10.1016/j.landusepol.2012.11.010.

Lieskovský, J. \& Kenderessy P. (2014). Modelling the effect of vegetation cover and different tillage practices on soil erosion in vineyards: A case study in Vráble (Slovakia) using WATEM/SEDEM. Land Degrad. Dev., 25(3), 288-296. DOI: 10.1002/ldr.2162.

Linkeš, V., Pestún, V. \& Džatko M. (1996). Príručka pre použivanie máp bonitovaných pôdno-ekologických jednotiek. Bratislava: Výskumný ústav pôdnej úrodnosti.

Maglocký, Š. (2002). Potenciálna prirodzená vegetácia 1 : 500 000. In Atlas krajiny SR (p. 114). Bratislava: MŽP SR, Banská Bystrica: SAŽP.

Matečný, I., Jenčo, M. \& Matečná G. (2010). Sklon reliéfu ako súčast kritérií pre plnenie environmentálne šetrných postupov v polnohospodárstve Slovenskej republiky. Acta Geographica Universitatis Comenianae, 54(1), 33-52.

Matečný, I. (2014). Spatial identification of vineyards - a prerequisite for maintainting them as a part of the cultural landscape heritage. Acta Environmentalica Universitatis Comenianae, 22(2), 26-41.

Mazúr, E. \& Lukniš M. (1986). Geomorfologické členenie SSR a ČSSR. Atlas SSR. Bratislava: SAV.

Minár, J. et al. (2001). Geoekologický (komplexný fyzickogeografický) výskum a mapovanie vo velkých mierkach. Bratislava: Geografika.

Ministerstvo pôdohospodárstva a rozvoja vidieka SR (2014). Špecifikácie vín chránených označením pôvodu (CHOP) a chránených zemepisných označení (CHZO). [online]. Dostupné na internete: http://www.mpsr.sk/ index.php?navID=934\&navID2=934\&sID $=40 \&$ id $=7226$ [cit. 16.4. 2017]

Opršal, Z., Šarapatka, B. \& Kladivo P. (2013). Land-use changes and their relationships to selected landscape parameters in three cadastral areas in Moravia (Czech Republic). Moravian Geographical Reports, 21(1), 41-50. DOI: 10.2478/mgr-2013-0004.

Pavloušek, P. (2011). Pěstovánírévy vinné - moderní vinohradnictví. Praha: Grada.

Pospísilová, D. (1981). Ampelografia ČSSR. Bratislava: Príroda.

Súlovský, M. \& Hriník D. (2016). Možnosti uplatnenia fyzickogeografických prístupov ako príspevku ku kvalitatívne orientovanej vinohradníckej produkcii Geographia Cassoviensis, 10(2), 175-192.

Štátny Geologický ústav Dionýza Štúra (2013). Geologická mapa Slovenska 1 : 50 000. [online] dostupné na: http:// mapserver.geology.sk/gm50js [cit. 28.10.2016]. Bratislava: ŠGÚDŠ.

Tarasovičová, Z., Saksa, M., Blažík, T. \& Faltan V. (2013). Changes in agricultural land use in the context of ongoing transformational processes in Slovakia. Agriculture (Polnohospodárstvo), 59(2), 49-64.

Tomasi, D., Gaiotti, F. \& Jones G.V. (2013). The power of the terroir: thecase study of prosseco wine. Berlin: Springer Science\& Business Media.

Torma, S. (1999). Draslík - dôležitá živina v pôde a rastline. Bratislava: Výskumný ústav pôdoznalectva a ochrany pôdy.

Tremboš, P., Mičian, L., Minár, J. \& Hradecký J. (2009). Geoekológia [CD]. Bratislava: PF UK.

Vanek, G. et al. (1996). Vinič 3. Pestovanie. Bratislava: Príroda.

VÚPOP (2014). Morfogenetický klasifikačný systém pôd Slovenska. Bazálna referenčná taxonómia. Bratislava: Výskumný ústav pôdoznalectva a ochrany pôdy NPPC.

Vyhláška Ministerstva pôdohospodárstva a rozvoja vidieka SR č. 338/2005 Z.z. ktorou sa ustanovujú podrobnosti o postupe pre odber pôdnych vzoriek, spôsobe a rozsahu vykonávania agrochemického skúšania pôd, zistovania pôdnych vlastností lesných pozemkov a o vedení evidencie hnojenia pôdy a stavu výživy rastlín na polnohospodárskej pôde a na lesných pozemkoch.

Vyhláška Ministerstva pôdohospodárstva a rozvoja vidieka SR č. 151/2016 Z. z., ktorou sa ustanovujú podrobnosti o agrochemickom skúšaní pôd a o skladovaní a používaní hnojív.

Výskumný ústav pôdoznalectva a ochrany pôdy (2013). Bonitované pôdno-ekologické jednotky - mapová služba. [online] dostupné na: http://www.podnemapy.sk/portal/verejnost/bpej/bpej.aspx [cit. 19.11.2016]

Základná mapa SR 1 : 10 000. Web Map Service. Slovenská agentúra životného prostredia. GeoData geografické údaje. 2017. [online] dostupné na: http://www.geodata.sk/Default.aspx?GrpID=33 [cit. 4. 3. 2017] 